ks. Tadeusz Zadykowicz Katolicki Uniwersytet Lubelski Jana Pawła II

\title{
Początek ludzkiego życia - z perspektywy nauczania Kościoła katolickiego. Próba określenia oraz konsekwencje etyczne
}

\section{THE BEGINNING OF HUMAN LIFE FROM THE PERSPECTIVE OF THE TEACHING OF THE CATHOLIC CHURCH: AN ATTEMPT TO DEFINE THE PHENOMENON AND ITS ETHICAL IMPLICATIONS}

Man remains a mystery. Despite the discoveries in the field of genetics, the beginnings of his life are also a secret. Facing this mystery and contrary to all ideologies, the Catholic Church attempts to create a model of mentality that favours life. It also makes its contribution to building a culture of life, so that affirmation of personal dignity of man became a foundation to all references in both medicine and social life. Nowadays, such actions require a consensus of opinions of all Christians as to the beginnings of human life. Its purpose is not so much the defence of moral principles as long as the defence of fundamental rights and dignity of man - from the very moment of his existence - which are increasily at risk today.

Key words: human life, bioethics, ecumenism, abortion, in vitro, contraception.

Coraz dojrzalszy i stale postępujący - choć nie bez trudności - dialog ekumeniczny dojrzewa do podjęcia również problematyki moralnej ${ }^{1}$. Po kilku dekadach kontaktów i dyskusji głównie doktrynalnych, Kościoły chrześcijańskie uświadomiły sobie potrzebę wspólnego otwarcia

Por. S. Nowosad, Teologia moralna w kontekście ekumenicznym, [w:] Polska teologia moralna. Czterdzieści lat po Soborze Watykańskim II, J. Nagórny, J. Gocko (red.), Lublin 2006, s. 160. 
się na prawdę o człowieku i jego życiu. W dzisiejszym świecie bowiem większą wagę przywiązuje się do kwestii ludzkiego działania w obszarze dobra i zła niż do prawd wiary, które dla człowieka żyjącego w zsekularyzowanym społeczeństwie, nie mają aż tak wielkiego znaczenia. W takich uwarunkowaniach szczególnej rangi nabiera wspólne świadectwo, którego ważnym przedmiotem jest promocja wartości życia ludzkiego na każdym jego etapie. To świadectwo jest potrzebne zwłaszcza ze względu na liczne zagrożenia, na jakie dzisiaj wystawione jest to życie już u jego początków. Wiele z tych zagrożeń rodzi się ze złej woli, ale wiele też z niewiedzy o początkach życia. Od kiedy więc zaczyna się człowiek? Kiedy staje się on podmiotem praw? Jakie są moralne konsekwencje określenia początków życia ludzkiego? Kościół katolicki zawarł swoje nauczanie na te tematy w licznych dokumentach i oficjalnych wypowiedziach, wśród których należy wymienić encyklikę Jana Pawła II Evangelium vitae (1995), Instrukcję Kongregacji Nauki Wiary o szacunku dla rodzącego się życia ludzkiego i o godności jego przekazywania Donum vitae (1987) oraz tejże Kongregacji Instrukcje Quaestio de abortu (1974) oraz Dignitas personae (2008). Nie bez znaczenia jest w tym względzie również działalność Papieskiej Akademii Pro vita oraz Papieskiej Rady ds. Duszpasterstwa Chorych i Służby Zdrowia, które starają się podejmować dialog ze współczesnym światem wokół pytań o człowieka, o sens jego życia, zwłaszcza wobec nowych osiągnięć biomedycyny.

\section{Człowiek „od chwili poczęcia”}

Kościół katolicki wiąże początek życia ludzkiego z „chwilą poczęcia", a więc z momentem utworzenia się zygoty ${ }^{2}$. Stwierdzenie takie pojawia się w Magisterium w związku z podkreśleniem świętości i nienaruszalności życia ludzkiego na każdym jego etapie, choć w świetle współczesnej wiedzy wiadomo, że mówienie o „momencie” poczęcia jest nieprecyzyjne, ponieważ jest ono raczej trwającym około doby procesem, który rozpoczyna się penetracją błony komórki jajowej przez plemnik, a kończy się wytworzeniem nowego, diploidalnego garnituru chromosomowego ${ }^{3}$. W każdym razie już wniknięcie plemnika do komórki jajowej inicjuje określony i nieodwracalny proces zmierzający do ukształtowania się nowej istoty i w tym sensie może być ono uznane

2 Por. Kongregacja Nauki Wiary, Instrukcja o szacunku dla rodzacego się życia ludzkiego i o godności jego przekazywania (dalej: DV), I, 1.

3 Por. M. Machinek, Życie w dyspozycji człowieka. Wybrane problemy etyczne u poczattku życia ludzkiego, Olsztyn 2004, s. 89. 
za „moment” poczęcia. Od tego momentu nie można już sprowadzić nowej istoty jedynie do jej dziedzictwa genetycznego, które stanowi jej bazę biologiczną i podstawę oczekiwania co do przyszłego życia ${ }^{4}$. „W rzeczywistości - pisze Jan Paweł II cytując Instrukcję Questio de abortu - «od chwili zapłodnienia komórki jajowej rozpoczyna się życie, Wiara które nie jest życiem ojca ani matki, ale nowej istoty ludzkiej, która rozwija się samoistnie. Nie stanie się nigdy człowiekiem, jeżeli nie jest nim od tego momentu. Tę oczywistą prawdę, zawsze uznawaną, [...] nowoczesna genetyka potwierdza cennymi dowodami. Ukazała ona, że od pierwszej chwili istnieje dokładny program tego, kim będzie ta żywa istota: człowiekiem, tym konkretnym człowiekiem, którego cechy szczególne są w pełni określone. Od zapłodnienia rozpoczynają się dzieje życia człowieka, choć potrzeba czasu, aby każda z jego wielkich potencjalnych zdolności w pełni się ukształtowała i mogła być wykorzystana»" Dalsza część tej wypowiedzi odnosi się do wielowiekowych dyskusji i kontrowersji wokół momentu tzw. animacji. Papież pisze: „Chociaż obecność rozumnej duszy nie może być stwierdzona w żaden sposób doświadczalnie, to jednak sama wiedza naukowa o embrionie ludzkim dostarcza cennej wskazówki dla rozumowego rozpoznania obecności osobowej od pierwszego momentu pojawienia się życia ludzkiego" .

Kościół dokładnie nie określa momentu animacji. Kwestia ta była przedmiotem sporu w ciągu wieków ${ }^{7}$. Wytworzyły się nawet dwie odmienne koncepcje: animacji równoczesnej oraz animacji sukcesywnej. Argumenty używane w tym sporze pojawiają się czasami i współcześnie w kontekście dyskusji dotyczącej moralnego i prawnego statusu embrionu ${ }^{8}$. Nie odgrywają one dzisiaj jednak aż tak wielkiej roli. De-

4 Por. Jan Paweł II, Przemówienie do uczestników Sympozjum na temat Aspekty prawne i etyczne badań nad genomem ludzkim zorganizowanego przez Papieską Akademię Nauk „Etyczne problemy genetyki” (1993) nr 6-7, „L'OssRom” (PL) 15(1994), nr 2, s. 37-38.

5 Jan Paweł II, Encyklika o wartości i nienaruszalności życia ludzkiego Evangelium vitae (dalej: EV), 60.

$\mathrm{EV}, 60$.

7 Szczegółowo opisuje te kontrowersje J. Wróbel. Por. Człowiek i medycyna. Teologicznomoralne podstawy ingerencji medycznych, Kraków 1999, s. 71-80. Por. także: R. Otowicz, Etyka życia. Bioetyczny i teologiczny kontekst problematyki życia poczętego, Kraków 1998, s. 147-184.

8 Np. współcześni zwolennicy dopuszczalności eksperymentów na embrionach przywołują naukę o „nieuformowanym”, a więc jeszcze nieanimowanym płodzie, która od XII wieku zadomowiła się na długie stulecia w chrześcijańskiej dyscyplinie. W świetle tej nauki aborcja płodu w czasie poprzedzającym wlanie 
klaracja Kongregacji Nauki Wiary Questio de abortu stwierdza jedynie, że nawet w wypadku wątpliwości co do momentu animacji należy przyznać embrionowi ludzkiemu nieograniczone prawo do życia, gdyż

to w płodzie zaczyna się życie ludzkie (o którym wiadomo z biologii), które i przygotowuje się do przyjęcia duszy, i jej wymaga; dzięki niej doskonali się natura otrzymana od rodziców. [...] Jeżeli zaś tzw. wlanie duszy uważa się tylko za prawdopodobne (czegoś przeciwnego nie da się nigdy ustalić), to odebranie życia jest tym samym, co narażenie się na niebezpieczeństwo zabicia człowieka, który jest nie jakby w oczekiwaniu duszy, ale już nią obdarzony9 .

Zatem w wypadku wątpliwości, w odniesieniu do embrionu ludzkiego należy zawsze kierować się tucjorystyczną zasadą in dubio pro reo, która w przypadku embrionu przybierze postać zasady in dubio pro vita ${ }^{10}$.

Kościół katolicki opowiada się więc przeciw próbom ustalenia jakiegokolwiek innego momentu rozpoczynającego godne ochrony i szacunku indywidualne i niepowtarzalne życie ludzkie niż moment poczęcia. Odwołuje się przy tym m.in. do prawdy o Wcieleniu Syna Bożego oraz do dogmatu o Niepokalanym Poczęciu ${ }^{11}$. Opowiada się również przeciwko rozdzieleniu znaczeń terminów „zapłodnienie” i ,poczęcie"12 oraz obecnemu w niektórych dokumentach międzynarodowych rozróżnieniu między ,istotą ludzką” i „osobą ludzką”. Takie rozróżnienie prowadzi do uznania prawa do życia i integralności fizycznej jedynie osób już narodzonych. Kościół katolicki uczy, że każda istota ludzka od momentu poczęcia aż do naturalnej śmierci posiada nienaruszalne prawo do życia i zasługuje na pełny szacunek należny osobie ludzkiej ${ }^{13}$.

Swoją naukę na temat początku życia ludzkiego Kościół opiera nie tylko na Objawieniu, ale także na współczesnej wiedzy medycznej z zakresu rozwoju prenatalnego człowieka, która m.in. nie pozwala na podtrzymanie poglądu na temat animacji sukcesywnej. To także w świetle tej wiedzy nie da się wskazać istotnej jakościowej cezury,

duszy przez wielu teologów nie była traktowana jako mord, choć uchodziła za poważny grzech.

nr 13

Por. M. Machinek, Życie w dyspozycji człowieka..., dz. cyt., s. 116.

Por. P. Kieniewicz, Problem animacji w kontekście dogmatu o Wcieleniu i Niepokalanym Poczęciu, RT 55(2008), z. 3, s. 107-120.

Rozdzielenie to oznaczałoby, że przez jakiś czas od zapłodnienia rozwija się ludzkie (biologiczne) życie, które nie jest człowiekiem.

Por. DV, 1. 
która pozwoliłaby na zdefiniowanie przedpersonalnego stanu rozwojowego człowieka ${ }^{14}$. Przeciwnie, poczęcie inicjuje cykl rozwojowy, nowej, obdarzonej unikalną informacją genetyczną istoty ludzkiej, która nie jest „potencjalną osobą”, ale co najwyżej „potencjalnym dorosłym", aktualizującym coraz bardziej swoje osobowe możliwości. Kościół odrzuca więc teorię opóźnionej - uzależnionej od stopnia zaniku zjawiska totipotencjalności - hominizacji i preanimowanej zygoty ${ }^{15}$. Odrzuca również uzależnienie godności osobowej od stopnia świadomości, stopnia aktualizacji cech osobowościowych, jak też od stopnia akceptacji ze strony otoczenia. Każda osoba ludzka od chwili poczęcia stanowi jednorazową i niepowtarzalną rzeczywistość. Nie jest ona produktem aktu fizjologicznego; nie jest przedmiotem czyichś uprawnień; nie jest własnością rodziców. Stąd wynikająjej prawa. Stąd też wynikają obowiązki wobec niej.

\section{Moralne konsekwencje określenia początku życia}

Określenie początku życia ludzkiego jest źródłem imperatywów moralnych. Kościół, opowiadając się za uznaniem tego początku w momencie zapłodnienia, przypomina o obowiązku bezwarunkowego szacunku względem istniejącej już wówczas istoty ludzkiej. Od począt$\mathrm{ku}$, od chwili poczęcia człowiekowi przysługują takie same prawa jak każdej istocie ludzkiej w jej integralności cielesnej i duchowej. Istota ludzka winna być szanowana i traktowana jako osoba od chwili swego poczęcia i dlatego należy się jej uznanie wszystkich praw osoby, z nienaruszalnym prawem do życia na czele ${ }^{16}$. Nawet gdyby uznać pozytywne wątpliwości co do statusu osobowego embrionu ludzkiego w pierwszych stadiach jego rozwoju, to wobec możliwości, iż niszcząc embrion, uśmierca się osobę ludzką, należy traktować go z pełnym szacunkiem przysługującym człowiekowi ${ }^{17}$.

Wyprowadzając moralne konsekwencje z uznania początków życia ludzkiego w momencie zapłodnienia, Kościół katolicki operuje pojęciem niezbywalnej, niestopniowalnej godności, która przysługuje każdej osobie ludzkiej jako wartości samej w sobie; wartości tak cennej, że nie wolno jej nigdy używać jako środka do celu, ponieważ jest ona celem samym w sobie. Podstaw tej godności Kościół upatruje

${ }_{14} \quad$ Por. M. Machinek, Życie $w$ dyspozycji człowieka..., dz. cyt., s. 116; J. Wróbel, Człowiek i medycyna..., dz. cyt., s. 82.

$15 \quad$ M. Machinek, Życie $w$ dyspozycji człowieka..., dz. cyt., s. 95.

16 Por. DV I, 1.

$17 \quad$ Por. M. Machinek, Życie $w$ dyspozycji człowieka..., dz. cyt., s. 117. 
w stworzeniu człowieka na obraz i podobieństwo Boga oraz w odkupieniu i przeznaczeniu do wiecznej szczęśliwości ${ }^{18}$. Nie znaczy to jednak, że Kościół uważa, że godność ta jest możliwa do odkrycia i uznania wyłącznie na płaszczyźnie religijnej. Niepowtarzalną wartość życia jako jedno z podstawowych dóbr człowieka pozwala odkryć powszechne ludzkie doświadczenie. Niezależnie od tego, czy ktoś wierzy w Boga czy nie, osobiście doświadcza, że życie zostało mu „dane"19. Odpowiedź na ten dar domaga się tworzenia „kultury życia”, która nie jest czymś specyficznie chrześcijańskim, choć trzeba przyznać, że dzisiaj to właśnie chrześcijanie są jej głównymi rzecznikami ${ }^{20}$.

Jedynym adekwatnym odniesieniem do osoby ludzkiej jest postawa afirmacji, postawa miłości ${ }^{21}$. Postawa ta znajduje swój wyraz w uznaniu prawa do życia oraz innych praw, jakie przysługują osobie ludzkiej $\mathrm{z}$ racji bycia człowiekiem, a więc nie z czyjegokolwiek nadania. $\mathrm{Na}$ uwagę zasługuje również fakt, że Kościół katolicki - wbrew temu, co się niekiedy głosi - uznaje, że w tej godności bierze również udział ludzkie ciało. Jako konstytutywny element człowieka, poprzez który wyraża on siebie, uczestniczy w życiu świata i społeczeństwa, winno być szanowane ${ }^{22}$. Jego godność potwierdzona w prawdzie o Wcieleniu Syna Bożego i dopełniona perspektywą Zmartwychwstania domaga się nieustannej afirmacji oraz przezwyciężania wszystkiego, co tę godność narusza.

Sobór Watykański II, Konstytucja duszpasterska o Kościele w świecie współczesnym Gaudium et spes (dalej: KDK), 12-22; Katechizm Kościoła Katolickiego (dalej: KKK), 356; EV, 25. Por. także: S. Warzeszak, Teologiczne podstawy etyki odpowiedzialności za życie, [w:] Życie człowieka jako zobowiazujący dar, A. Skreczko, J. Zabielski (red.), Białystok 2011, s. 43-45; M. Machinek, Spór o status ludzkiego embrionu, Olsztyn 2007, s. 229-233; J. Wróbel, Życie od Boga i dla Boga, [w:] Jan Pawet II. Evangelium vitae. Tekst i komentarze, T. Styczeń, J. Nagórny (red.), Lublin 1997, s. 179-208.

Por. R. Otowicz, Ideologiczne zagrożenia daru życia w centrum uwagi wspótczesnej kwestii społecznej, [w:] Życie - dar nienaruszalny. Wokót encykliki Evangelium vitae, A. Młotek, T. Reroń (red.), Wrocław 1995, s. 193.

Por. J. Merecki, Życie ludzkie a życie osobowe. Kilka uwag na marginesie 60. numeru encykliki Evangelium vitae, [w:] Jan Pawet II. Evangelium vitae. Tekst $i$ komentarze..., dz. cyt., s. 351; J. Nagórny, Antropologiczny fundament troski o życie izdrowie, [w:] Ksiądz Janusz Nagórny. Wartośćżycia ludzkiego, K. Jeżyna, J. Gocko, W. Rzepa (red.), Lublin 2009, s. 39.

21 Por. K. Wojtyła, Miłość i odpowiedzialność, Lublin 2001, s. 42-43. Por. także: J. Zabielski, Odpowiedzialność za życie, Białystok 2007, s. 171-172.

22 Por. J. Nagórny, Szacunek dla ciała ludzkiego, [w:] Ksiądz Janusz Nagórny. Wartość życia ludzkiego..., dz. cyt., s. 113; Tenże, Zagrożona wartość - ludzkie ciało, tamże, s. 121 . 
Taki szacunek należy się człowiekowi niezależnie od miejsca jego poczęcia (in vivo czy in vitro) oraz od wieku (przed czy po implantacji). Kościół katolicki, podzielając opinię co do niemożliwości sformułowania cezur człowieczeństwa w odniesieniu do istot ludzkich, głosi zasadę quod generatur ab homine homo est. To, co rodzi się z człowieka, musi być traktowane jako „ktoś”, nigdy „coś”. Istnieje jednak współcześnie wiele zagrożeń życia już u jego początków; wiele sytuacji, gdy człowiek sprowadzany jest do roli przedmiotu. Co więcej, zagrożenia te ukazywane są jako wyraz postępu, jako osiągnięcie nauki. Dlatego Kościół, opowiadając się za uznaniem początku życia ludzkiego w momencie poczęcia i wyprowadzając $z$ tego konsekwencje etyczne, wskazuje jednocześnie na zło konkretnych działań, które zwracają się przeciwko człowiekowi od pierwszych chwil jego istnienia.

\section{Aborcja, in vitro, antykoncepcja - w służbie czy przeciwko człowiekowi?}

Współczesne nauki empiryczne, a zwłaszcza medycyna, posiadły umiejętność ingerowania w ludzkie życie już u jego początków. Odkrycia w tym zakresie mają jednak charakter ambiwalentny. $Z$ jednej strony dają możliwość przezwyciężania cierpienia, chorób, ale z drugiej strony otwierają pole do nadużyć, których skutki dziś jeszcze trudno przewidzieć. Dlatego głos Kościoła katolickiego na temat początków życia nie ma charakteru wyłącznie teoretycznej refleksji o charakterze ogólnym, ale odnosi się do szeregu zjawisk szczegółowych, dla których godność osoby ludzkiej od pierwszej chwili poczęcia pełni rolę kluczowej kategorii argumentacyjnej. Wypowiedzi Magisterium na ten temat są tym częstsze, im większa jest liczba zagrożeń, na jakie narażona jest godność ludzka oraz w miarę jak pojawiają się nowe formy tych zagrożeń (przerywanie ciąży, zabiegi in vitro, różnego rodzaju eksperymenty, diagnostyka prenatalna, badania z zakresu inżynierii genetycznej).

Skrajną formą zamachu na życie u jego początków jest aborcja. Niszcząc już istniejące życie, bezpośrednio łamie ona Boże przykazanie „nie zabijaj”. Jako dobrowolne zabójstwo niewinnej osoby ludzkiej jest zawsze poważnym nieładem moralnym ${ }^{23}$, które Kościół katolicki - po zaistnieniu skutku - sankcjonuje karą ekskomuniki wiążącej mocą samego prawa ${ }^{24}$. Istnieje jednak o wiele więcej form tych zamachów, które w obecnych czasach są niekiedy przedstawiane jako dobrodziejstwo,

\footnotetext{
23 Por. EV, 62.

Por. KKK, 2272; Kodeks Prawa Kanonicznego (dalej: KPK), 1398 i 1314.
} 
jako osiągnięcie, a nawet jako forma służby człowiekowi, podczas gdy w rzeczywistości stanowią one okazję do nowych zamachów na ludzkie życie. Należą do nich sztuczne zapłodnienie oraz antykoncepcja. Ocena tych działań odwołuje się do godności człowieka, wartości życia ludzkiego oraz sensu ludzkiej płciowości.

Kontakt seksualny między mężczyzną a kobietą nie może być rozpatrywany jedynie na płaszczyźnie biologicznej. Jest to nade wszystko część osobowego, cielesno-duchowego związku dwojga istot ludzkich. Ten osobowy związek stanowi podłoże dla daru Boga, którym jest dziecko. Ludzkie działanie stanowi bowiem akt prokreacji, tzn. współdziałania z Tym, który jest jedynym Stwórcą, i który czyni człowieka „współpracownikiem” w swoim dziele stworzenia; „współstworzycielem", do którego należy odpowiedzialna decyzja o powołaniu do życia nowego człowieka. Dlatego Kościół katolicki sprzeciwia się sytuacjom, gdy człowiek mobilizuje wszystkie dostępne środki techniczne, by zrealizować marzenie o posiadaniu dziecka (jak ma to miejsce w zabiegach in vitro), jak i takim, gdy posiadanie potomstwa przestaje być traktowane jako znak błogosławieństwa Bożego, a staje się przeszkodą w samorealizacji (jest to postawa charakterystyczna dla mentalności antykoncepcyjnej).

W przypadku zapłodnienia in vitro jednym z głównych (choć nie jedynych) aspektów oceny etycznej jest zagrożenie dla życia embrionów ${ }^{25}$. Techniczna ingerencja $\mathrm{w}$ proces zapłodnienia wiąże się $\mathrm{z}$ redukcją, selekcją, kriokonserwacją, co w praktyce - przynajmniej na obecnym poziomie medycyny - oznacza pozbawienie życia istot ludzkich i jako takie jest przez Kościół katolicki uznawane za niegodziwe. Negatywna ocena tego typu zabiegów wynika także z tego, że

$25 \quad$ Wszystkie aspekty moralnej oceny zapłodnienia in vitro zostały zawarte w encyklice Jana Pawła II Evengelium vitae: „Także różne techniki sztucznej reprodukcji, które wydają się służyć życiu i często są stosowane z tą intencją, w rzeczywistości stwarzają możliwość nowych zamachów na życie. Są one nie do przyjęcia z punktu widzenia moralnego, ponieważ oddzielają prokreację od prawdziwie ludzkiego kontekstu aktu małżeńskiego, a ponadto stosujący te techniki do dziś notują wysoki procent niepowodzeń: dotyczy to nie tyle samego momentu zapłodnienia, ile następnej fazy rozwoju embrionu wystawionego na ryzyko rychłej śmierci. Ponadto w wielu przypadkach wytwarza się większą liczbę embrionów, niż to jest konieczne dla przeniesienia któregoś z nich do łona matki, a następnie te tak zwane «embriony nadliczbowe» są zabijane lub wykorzystywane w badaniach naukowych, które mają rzekomo służyć postępowi nauki i medycyny, a w rzeczywistości redukują życie ludzkie jedynie do roli «materiału biologicznego», którym można swobodnie dysponować”. Nr 14. Por. także: J. Nagórny, Technicyzacja ludzkiej prokreacji. Spojrzenie teologa moralisty, [w:] Ksiądz Janusz Nagórny. Wartość życia ludzkiego..., dz. cyt., s. 149170; Tenże, Moralne aspekty zapłodnienia in vitro, tamże, s. 171-194. 
stanowią one próbę zawładnięcia przez człowieka władzy nad źródłami życia, a samą osobę ludzką sprowadzają do przedmiotu reprodukcji, technik laboratoryjnych, podczas gdy ma być ona owocem prokreacji. To zawładnięcie źródeł życia dokonuje się także - choć oczywiście w inny sposób - w postawach antykoncepcyjnych. Kościół katolicki nie redukuje płciowości do funkcji prokreacyjnej, ale widzi w niej płaszczyznę dla miłosnego zjednoczenia mężczyzny i kobiety. Odważnie występuje jednak przeciwko takim koncepcjom płciowości, w których współżycie zostaje sprowadzone jedynie do przeżycia dostarczającego przyjemności. Wskazuje także na wzajemną zależność antykoncepcji i aborcji mimo odmiennej natury tych działań i ich ciężaru moralnego ${ }^{26}$.

Należy zaznaczyć, że w swoim uzasadnieniu moralnego zła zapłodnienia pozaustrojowego oraz antykoncepcji, Kościół katolicki odwołuje się nie tylko do argumentów stricte teologicznych, ale także antropologicznych, ściślej - personalistycznych, a także społecznych i medycznych, które często mogą stanowić jedyne miejsce spotkania $\mathrm{w}$ dialogu w pluralistycznym społeczeństwie. Dlatego tak ważne jest rozpatrywanie zagadnień bioetycznych nie tylko w kategoriach zła i grzechu, ale podejście pozytywne, ukazujące powołanie człowieka do troski o życie i do promocji życia jako największego daru ${ }^{27}$. Wskazane ingerencje w początki życia ludzkiego są wyrazem egoizmu oraz etyki utylitarystycznej i dlatego Kościół katolicki ocenia je jako niegodziwe. Jego głos jest także głosem sprzeciwu wobec tendencji hedonistycznych, postulujących wyzwolenie się z jakiegokolwiek obowiązku na korzyść doznań przyjemnościowych. Kościół katolicki nie godzi się też na wszelki redukcjonizm sprowadzający człowieka do jego cielesności.

Człowiek pozostaje tajemnicą. Mimo odkryć w dziedzinie genetyki, tajemnicą pozostają także początki jego życia. Wobec tej tajemnicy i wbrew wszelkim ideologiom, Kościół katolicki zabiega o wytworzenie się w społeczeństwie mentalności przychylnej życiu. Wnosi także swój wkład w budowanie kultury życia, tak by afirmacja osobowej godności człowieka stała się fundamentem wszelkich odniesień zarówno na płaszczyźnie medycyny, jak i w życiu społecznym. W dzisiejszych

26 Por. T. Zadykowicz, Antykoncepcja, [w:] Duszpasterstwo rodzin. Refleksja naukowa i działalność pastoralna, R. Kamiński, G. Pyźlak, J. Goleń (red.), Lublin 2013, s. 236-237.

27 Por. P. Morciniec, Bioetyka jako nowy obszar badawczy teologii moralnej, [w:] Polska teologia moralna. Czterdzieści lat po Soborze Watykańskim II..., dz. cyt., s. 178. 
czasach działania takie domagają się zgodnego świadectwa wszystkich chrześcijan o początkach ludzkiego życia. Celem tego świadectwa jest nie tyle obrona zasad moralnych, ile obrona podstawowych praw i godności człowieka od pierwszej chwili jego istnienia - praw i godności coraz bardziej zagrożonych.

Słowa kluczowe: życie ludzkie, bioetyka, ekumenizm, aborcja, in vitro, antykoncepcja. 